\title{
KUALITAS FISIK PELET AYAM BROILER PERIODE AKHIR DENGAN PENAMBAHAN FESES TERNAK DAN BAHAN PEREKAT YANG BERBEDA
}

\author{
I. RAHMANA, D. A. MUCRA DAN D. FEBRINA \\ Fakultas Pertanian dan Peternakan Universitas Islam Negeri Sultan Syarif Kasim Riau \\ Kampus Raja Ali Haji Jl. H. R. Soebrantas Km 16 Pekanbaru \\ Email: indrana03@gmail.com
}

\begin{abstract}
The study aimed to know the physical quality of pellets for finisher period added different feces and adhesive matter. The experiment design was randomized complety block design factorial (RCBD) with two factors and three replications. The first factor was feces (goat feces, cattle feces, buffalo feces) and the second factor was adhesive matter (tapioca flour, eeg white, sago flour). Physical observation were water content, specific gravity, bulk density, compressed bulk density, angle of repose, and the durability of pellet. The result showed that addition type feces influenced water content, specific gravity, bulk density, compressed bulk density, angle of repose and the durability of pellet form. The result showed that addition adhesive matter influenced bulk density, compressed bulk density, the durability of pellet form.Interaction the addition of cattle feces and different adhesive matter in water content, specific gravity, compressed bulk density, angle of repose and the durability of pellet. Interaction buffalo feces and tapioca flour best quality.
\end{abstract}

Keywords : feces, adhesive, pellet, bulk density, durability, water content.

\section{PENDAHULUAN}

Proses pengolahan ransum pada pabrik pakan merupakan proses produksi menggunakan mesin dan menghasilkan ransum dalam bentuk mash, pellet dan crumble. Dewasa ini kecenderungan pakan diberikan kepada ternak dalam bentuk komplit (complete feed) karena dinilai sangat efektif. Beberapa penelitian menunjukkan pakan komplit berbentuk pelet lebih acceptable (bisa diterima) ternak, pemberiannya mudah dan tidak berdebu (Krisnan dan Ginting, 2009).

Ternak yang memperoleh pakan pelet memiliki performans lebih baik dan konversi pakan lebih rendah dibandingkan pakan mash. Keunggulan pakan bentuk pelet adalah : (1) Bulk Density (Kerapatan Tumpukan) lebih tinggi dibandingkan pakan bentuk lain sehingga daya angkut kendaraan lebih maksimal, (2) Komposisi pelet relatif merata karena pencampuran yang teliti sehingga tidak ada segregasi (pemisahan) didalamnya (Vanschoubrock et al., 1971).

Menurut Hartadi dkk.(1990) pellet dikenal sebagai bentuk massa dari bahan pakan atau ransum yang dibentuk dengan cara menekan dan memadatkan melalui lubang cetakan secara mekanis. Pelet merupakan hasil modifikasi dari mash yang dihasilkan dari pengepresan, sehingga pelet menjadi lebih keras (Jahan et al., 2006). Bentuk fisik pelet sangat dipengaruhi jenis bahan yang digunakan, ukuran pencetak, jumlah air, tekanan dan metode setelah pengolahan serta penggunaan bahan pengikat/ perekat untuk menghasilkan pelet dengan struktur yang kuat, kompak dan kokoh sehingga pelet tidak mudah pecah.

Feses ternak merupakan limbah yang berasal dari peternakan, umumnya hanya digunakan sebagai pupuk kandang sehingga pemanfaatannya sebagai pakan masih sangat terbatas. Seekor sapi mampu menghasilkan kotoran padat sekitar 23,6 $\mathrm{kg} / \mathrm{hari}$ dan cair 9,1 kg/hari (Undang, 2002). Pada penelitian Nugroho (2010) feses sapi dapat digunakan sebagai bahan baku alternatif, karena mengandung protein 17,08\%; lemak 0,81\%; karbohidrat $38,85 \%$ sehingga feses sapi bisa digunakan sebagai bahan tambahan dalam pembuatan pelet. Pemanfaatan feses ternak untuk campuran pelet akan 
memberikan keuntungan yaitu dapat menekan biaya produksi dan feses mengandung hampir semua unsur hara (Setyamidjaja, 1986).

Perekat berfungsi mengikat komponenkomponen pakan dalam bentuk pelet sehingga strukturnya tetap kompak. Perekat yang biasa digunakan pabrikpabrik makanan ternak adalah perekat sintetis seperti bentonit, dan lignosulfonat (Retnani $d k k ., 2010)$. Perekat sintetis relatif mahal sehingga perlu dicari alternatif bahan perekat dari bahan pakan lokal yang murah seperti tepung tapioka, tepung sagu maupun putih telur.

Tepung tapioka, tepung sagu dan putih putih mempunyai kandungan pati dan protein yang cukup tinggi. Scott et al., (1982) melaporkan tepung tapioka mengandung protein kasar (PK) 1,8\%; Energi Metabolisme (EM) $3720 \mathrm{kkal} / \mathrm{kg}$; lemak kasar (LK) 1,3\%; serat kasar 1,8\%. Menurut Lie (1980) kandungan nutrisi tepung sagu yaitu PK 1,4\%; EM 357 $\mathrm{kkal} / \mathrm{kg}$; LK 0,2\%; SK 0,2\%. Kandungan nutrisi putih telur yaitu PK $80 \%$ dan LK 0,2\% (Espada et al., 2012). Penelitian ini bertujuan untuk mengetahui pemanfaatan feses ternak dan bahan perekat yang berbeda dalam pembuatan pelet ayam broiler periode akhir.

\section{MATERI DAN METODE}

\section{Bahan dan Alat}

Bahan untuk pembuatan pelet adalah jagung halus, dedak padi, tepung ikan, tepung tapioka, tepung sagu, putih telur, minyak makan, feses sapi, feses kerbau dan feses kambing.

Peralatan yang digunakan adalah mesin grinder, baskom, sendok pengaduk, kantong plastik, blender, penyaring, neraca analitik, mesin pencetak pelet/pelleter, cawan, oven, gelas ukur, jangka sorong, batang pengaduk, corong, lempeng besi. Kandungan gizi bahan dan feses terlihat pada Tabel 1.

Tabel 1. Kandungan gizi bahan pakan dan feses ternak (\%).

\begin{tabular}{clrrrrrr}
\hline No & Bahan & \multicolumn{1}{c}{ PK } & \multicolumn{1}{c}{ LK } & \multicolumn{1}{c}{ SK } & \multicolumn{1}{c}{ Abu } & BETN & BK \\
\hline 1 & Jagung Halus & 8,58 & 2,47 & 1,97 & 4,08 & 82,90 & 87,28 \\
2 & Tepung Ikan & 52,01 & 5,36 & 0,99 & 28,73 & 12,91 & 82,67 \\
3 & Dedak Halus & 8,15 & 6,48 & 21,89 & 15,41 & 48,07 & 91,29 \\
4 & Feses Kambing & 12,61 & 1,48 & 25,00 & 15,05 & 51,03 & 84,55 \\
5 & Feses Sapi & 13,66 & 1,97 & 20,79 & 15,74 & 46,86 & 59,96 \\
6 & Feses Kerbau & 10,92 & 1,49 & 18,45 & 12,95 & 56,20 & 78,29 \\
\hline
\end{tabular}

Sumber : Laboratorium Ilmu Nutrisi dan Kimia Fakultas Pertanian dan Peternakan UIN Suska Riau 2015)

\section{Metode Penelitian}

Penelitian dilaksanakan di Laboratorium Agrostologi, Industri Pakan, dan Ilmu Tanah Fakultas Pertanian dan Peternakan UIN Suska Riau. Penelitian menggunakan Rancangan Acak Kelompok (RAK), pola faktorial yang terdiri dari 2 faktor, masing-masing perlakuan diulang 5 kali

Faktor A. Jenis Feses Ternak

A1. Feses Kambing

A2. Feses Sapi

A3. Feses Kerbau
Faktor B. Bahan Perekat

B1. Tepung Tapioka

B2. Putih Telur

B3. Tepung Sagu

\section{Pembuatan Pellet}

Feses sapi, kerbau dan kambing dijemur di bawah sinar matahari hingga kering, kemudian digiling halus. Jagung dan ikan juga digiling halus menggunakan mesin penghancur (grinder) menjadi tepung (mash). Setelah seluruh bahan digiling menjadi tepung (mash), semua bahan dicampur sesuai perlakuan 
kemudian diaduk hingga rata, selanjutnya bahan pakan dicetak menggunakan mesin pencetak pelet (pelleter). Bahan pakan yang sudah menjadi pelet selanjutnya dijemur hingga kering kemudian dilakukan uji kualitas fisik pelet di Laboratorium Agrostologi, Industri Pakan, dan Ilmu Tanah Fakultas Pertanian dan Peternakan UIN Suska Riau.

Parameter yang diukur adalah kadar air, berat jenis, kerapatan tumpukan, kerapatan pemadatan tumpukan, sudut tumpukan, dan ketahanan benturan.

\section{Analisis Data}

Data yang diperoleh diolah secara statistik menggunakan analisis keragaman menurut Rancangan Acak Lengkap (Steel and Torrie, 1995). Perbedaan antar perlakuan diuji menggunakan Duncan's Multiple Ranget Test (DMRT).

\section{HASIL DAN PEMBAHASAN}

\section{Kadar Air}

Hasil analisis ragam menunjukkan penambahan feses ternak mempengaruhi $(\mathrm{P}<0,05)$ kadar air, penambahan bahan perekat tidak mempengaruhi $(\mathrm{P}>0,05)$ kadar air. Interaksi antara feses ternak dan bahan perekat mempengaruhi $(\mathrm{P}<0,01)$ kadar air (Tabel 2).

Tabel 2. Rataan kadar air pelet unggas hasil penelitian.

\begin{tabular}{lcccc}
\hline \multirow{2}{*}{ Feses (A) } & \multicolumn{3}{c}{ Perekat (B) } & \multirow{2}{*}{ Rataan } \\
\cline { 2 - 4 } & Tapioka & Putih Telur & Sagu & \\
\hline Kambing & $10,09 \pm 0,69^{\mathrm{b}}$ & $16,06 \pm 2,35^{\mathrm{a}}$ & $14,59 \pm 6,41^{\mathrm{ab}}$ & $13,58^{\mathrm{AB}}$ \\
Sapi & $10,43 \pm 1,29^{\mathrm{b}}$ & $10,74 \pm 1,22^{\mathrm{b}}$ & $13,85 \pm 3,53^{\mathrm{ab}}$ & $11,67^{\mathrm{B}}$ \\
Kerbau & $18,05 \pm 4,15^{\mathrm{a}}$ & $10,71 \pm 2,01^{\mathrm{b}}$ & $15,71 \pm 3,68^{\mathrm{a}}$ & $14,82^{\mathrm{A}}$ \\
\hline Rataan & 12,86 & 12,50 & 14,72 &
\end{tabular}

Ket : Superskrip berbeda pada kolom dan baris yang sama menunjukkan berbeda sangat nyata $(\mathrm{P}<0,01)$. Huruf besar berbeda pada kolom yang sama menunjukan berbeda nyata $(\mathrm{P}<0,05)$.

Tabel 2 menunjukan interaksi $(\mathrm{P}<0,01)$ antara feses ternak dan perekat yang berbeda mempengaruhi kadar air pelet unggas. Kadar air pelet unggas dengan penambahan feses ternak dan perekat yang berbeda berkisar 10,09-18,05\%. Hasil penelitian ini berbeda dengan Sholihah (2011) yang menyatakan kadar air pelet dengan penambahan daun legum indigofera sp selama masa simpan berkisar 7-11\%. Sesuai pendapat Winarno et al., (1980) bahan pakan dengan kadar air $<14 \%$ memiliki tingkat keawetan dan daya simpan yang lebih tinggi.

Kadar air tertinggi terdapat pada pellet berbahan feses kerbau dan tapioka yaitu $18,05 \%$ dan kadar air terendah terdapat pada feses kambing dan tapioka yaitu $10,09 \%$. Tingginya kadar air dengan penambahan feses kerbau dan tapioka (18,05\%) diduga dipengaruhi kandungan bahan kering feses kerbau serta proses pencetakan pelet yang menghasilkan rongga udara pada pelet. Semakin tinggi bahan kering suatu bahan maka kadar air akan turun, sesuai pendapat Syarief dan Halid (1994) bahwa kadar air adalah banyaknya kandungan air dalam bahan berdasarkan berat kering yang dipengaruhi oleh jenis bahan, suhu dan kelembaban lingkungan. Pendapat ini didukung oleh Sholihah (2011) bahwa semakin tinggi kadar air menyebabkan berat jenis, kerapatan tumpukan, kerapatan pemadatan tumpukan dan Pellet Durability Index rendah serta nilai sudut tumpukan yang besar.

Kadar air yang didapatkan pada penelitian ini bervariasi yaitu 10,09$18,05 \%$, hal ini diduga berhubungan dengan kandungan nutrisi feses ternak yang digunakan. Hasil penelitian ini 
sesuai dengan Standar Nasional Indonesia (SNI) bahwa kadar air maksimum pellet adalah 14\% (Direktora Bina Produksi, 1997). Bahan pakan dengan kadar air $<14 \%$ memiliki tingkat keawetan dan daya simpan yang lebih lama dibandingkan keadaan segarnya yaitu pada kadar air yang lebih tinggi (Winarno dkk, 1980). Kadar air yang diperoleh pada penelitian ini lebih tinggi dengan kadar air yang dilaporkan Sholihah (2011) kadar air pelet dengan penambahan daun legume indigofera $s p$ selama masa simpan berkisar 7-11\%.

\section{Berat Jenis}

Hasil analisis ragam menunjukkan penambahan feses ternak yang berbeda memberikan pengaruh berbeda sangat nyata $(\mathrm{P}<0,01)$ terhadap berat jenis, penambahan bahan perekat yang berbeda memberikan pengaruh tidak berbeda nyata $(\mathrm{P}>0,05)$ terhadap berat jenis. Interaksi antara feses ternak dan bahan perekat yang berbeda memberikan pengaruh berbeda sangat nyata $(\mathrm{P}<0,01)$ terhadap berat jenis. Data hasil penelitian disajikan pada Tabel 3.

Tabel 3. Rataan nilai berat jenis pelet unggas hasil penelitian.

\begin{tabular}{lcccc}
\hline \multirow{2}{*}{ Feses $(\mathrm{A})$} & \multicolumn{3}{c}{ Perekat $(\mathrm{B})$} & \multirow{2}{*}{ Rataan } \\
\cline { 2 - 4 } Kambing & Tapioka & Putih Telur & Sagu & $1,17^{\mathrm{B}}$ \\
Sapi & $1,18 \pm 0,05^{\mathrm{d}}$ & $1,12 \pm 0,03^{\mathrm{e}}$ & $1,19 \pm 0,08^{\mathrm{dc}}$ & $1,25^{\mathrm{A}}$ \\
Kerbau & $1,22 \pm 0,04^{\mathrm{bcd}}$ & $1,28 \pm 0,04^{\mathrm{a}}$ & $1,24 \pm 0,03^{\mathrm{abcd}}$ & $1,24^{\mathrm{A}}$ \\
\hline Rataan & $1,25 \pm 0^{\mathrm{abc}}$ & $1,27 \pm 0,04^{\mathrm{ab}}$ & $1,19 \pm 0,03^{\mathrm{dc}}$ & 1,21 \\
\hline Ket : Superskrip berbeda pada kolom dan baris yang sama menunjukkan berbeda sangat nyata $(\mathrm{P}<0,01)$.
\end{tabular}

Berat jenis pelet dengan penambahan feses ternak dan perekat yang berbeda berkisar $1,18-1,28 \mathrm{~g} / \mathrm{cm}^{3}$, berat jenis yang diperoleh pada penelitian ini lebih rendah dibandingkan Rahmayeni (2002) berat jenis pelet yang ditambahkan perekat tepung tapioka adalah 1,27-1,38g/ $\mathrm{cm}^{3}$. Berat jenis tertinggi berasal dari pellet berbahan feses sapi dan putih telur $\left(1,28 \mathrm{~g} / \mathrm{cm}^{3}\right)$, tingginya berat jenis ini diduga kadar air feses sapi tinggi yang tinggi yaitu 40,03\%. Syarief dan Halid (1994) menyatakan kadar air bahan dipengaruhi oleh jenis bahan, suhu dan kelembaban lingkungan. Berat jenis pellet pada penelitian ini lebih rendah dari hasil penelitian Handayany (2010) berat jenis pellet berbahan $75 \%$ jerami jagung $+10 \%$ legum Indigofera $s p$. Ditambah 15\% jagung giling yaitu $1,32 \mathrm{~g} / \mathrm{cm}^{3}$.

Penambahan feses ternak yang berbeda mempengaruhi $(\mathrm{P}<0,01)$ berat jenis, hal ini diduga berhubungan dengan bahan baku pakan dan kadar air pelet yang berbeda. Kadar air pelet (Tabel 2) berkisar 12,50$14,72 \%$. Winarno et al., (1980) menyatakan kadar air pelet $<14 \%$ memiliki tingkat keawetan dan daya simpan yang lebih tinggi. Selain itu bahan baku dalam pembuatan pelet juga mempengaruhi kualitas hal ini diduga semakin halus bahan penyusun pelet maka kualitas pelet semakin baik. Hal ini didukung oleh pendapat Lim (1994) bahwa bahan baku pakan, tingkat kehalusan partikel sangat berpengaruh dalam uji berat jenis pelet.

\section{Kerapatan Tumpukan}

Kerapatan tumpukan pelet dengan penambahan feses dan bahan perekat yang berbeda dapat dilihat pada Tabel 4 .

Hasil analisis ragam menunjukkan penambahan bahan perekat dan feses yang berbeda mempengaruhi $(\mathrm{P}<0,01)$ kerapatan tumpukan dan tidak terdapat interaksi $(\mathrm{P}>0,05)$ antara penambahan feses ternak dan perekat yang berbeda terhadap kerapatan tumpukan pelet unggas. 
Tabel 4.Rataan kerapatan tumpukan pelet unggas hasil penelitian.

\begin{tabular}{|c|c|c|c|c|}
\hline \multirow{2}{*}{ Feses (A) } & \multicolumn{3}{|c|}{ Perekat (B) } & \multirow{2}{*}{ Rataan } \\
\hline & Tapioka & Putih Telur & Sagu & \\
\hline Kambing & $0,43 \pm 0,0071$ & $0,42 \pm 0,0134$ & $0,44 \pm 0,0089$ & $0,43^{\mathrm{A}}$ \\
\hline Sapi & $0,41 \pm 0,0167$ & $0,39 \pm 0,0084$ & $0,42 \pm 0,0084$ & $0,41^{\mathrm{B}}$ \\
\hline Kerbau & $0,39 \pm 0,0192$ & $0,37 \pm 0,0084$ & $0,39 \pm 0,0084$ & $0,38^{\mathrm{C}}$ \\
\hline Rataan & $0,41^{\mathrm{a}}$ & $0,39^{\mathrm{b}}$ & $0,42^{\mathrm{a}}$ & \\
\hline
\end{tabular}

Ket : Superskrip berbeda pada baris yang sama memberikan pengaruh berbeda sangat nyata $(\mathrm{P}<0,01)$

Huruf besar berbeda pada kolom yang sama menunjukkan berbeda sangat nyata $(\mathrm{P}<0,01)$.

Penambahan feses kambing, sapi dan kerbau dalam pembuatan pelet unggas mempengaruhi kerapatan tumpukan diduga berhubungan dengan kadar air dan bahan kering feses (bahan kering feses kambing $84,55 \%$, feses sapi $59,96 \%$, dan feses kerbau 78,29\%). Semakin tinggi kadar air bahan pakan akan berpengaruh terhadap kerapatan tumpukan, pendapat ini sesuai dengan pernyataan Suadnyana (1998) bahwa nilai kerapatan tumpukan menurun dengan semakin meningkatnya kadar air karena bahan akan mengembang dengan semakin tingginya kandungan air sehingga volume ruang yang dibutuhkan menjadi besar.

Penambahan perekat yang berbeda mempengaruhi $(\mathrm{P}<0,01) \quad$ kerapatan tumpukan pelet unggas. Kerapatan tumpukan pelet dengan penambahan putih telur memiliki nilai terendah, hal ini diduga putih telur berbentuk cair sehingga memudahkan bahan merekat dengan baik dibandingkan tepung tapioka dan tepung sagu. Penambahan tepung sagu dan tapioka memiliki rataan kerapatan tumpukan yang relatif sama diduga bahan perekat yang digunakan memiliki sifat pengikat dan terdapat kandungan pati yang sama.

Interaksi antara feses ternak dan bahan perekat tidak mempengaruhi $(\mathrm{P}>0,05)$ kerapatan tumpukan, dengan nilai berkisar $0,37-0,44 \mathrm{~g} / \mathrm{cm}^{3}$, nilai ini hampir sama dengan yang dilaporkan Handayany (2010) kerapatan tumpukan pellet berbasis jerami padi adalah $0,38 \mathrm{~g} / \mathrm{cm}^{3}$.

\section{Kerapatan Pemadatan Tumpukan}

Hasil analisis ragam menunjukan penambahan feses ternak dan bahan perekat yang berbeda mempengaruhi $(\mathrm{P}<0,01)$ kerapatan pemadatan tumpukan. Interaksi antara penambahan feses ternak dan perekat yang berbeda memberikan pengaruh berbeda sangat nyata $(\mathrm{P}<0,01)$ terhadap kerapatan pemadatan tumpukan (Tabel 5).

Tabel 5. Pemadatan tumpukan pelet unggas hasil penelitian.

\begin{tabular}{|c|c|c|c|c|}
\hline \multirow{2}{*}{ Feses (A) } & \multicolumn{3}{|c|}{ Perekat (B) } & \multirow{2}{*}{ Rataan } \\
\hline & Tapioka & Putih Telur & Tepung Sagu & \\
\hline Kambing & $0,46 \pm 0,0239 \mathrm{bc}$ & $0,44 \pm 0,0089 \mathrm{dc}$ & $0,49 \pm 0,0084^{a}$ & $0,47^{\mathrm{A}}$ \\
\hline Sapi & $0,43 \pm 0,0045^{\mathrm{de}}$ & $0,45 \pm 0,0235^{\mathrm{dc}}$ & $0,44 \pm 0,0055^{\mathrm{dc}}$ & $0,44^{\mathrm{B}}$ \\
\hline Kerbau & $0,48 \pm 0,0130^{a}$ & $0,42 \pm 0,0055^{\mathrm{e}}$ & $0,48 \pm 0,0207 \mathrm{ab}$ & $0,46^{\mathrm{A}}$ \\
\hline Rataan & $0,46^{\mathrm{b}}$ & $0,44^{\mathrm{c}}$ & $0,47^{a}$ & \\
\hline
\end{tabular}

Ket : Superskrip berbeda pada baris dan kolom yang sama menunjukkan berbeda sangat nyata $(\mathrm{P}<0,01)$. Huruf besar berbeda pada kolom yang sama menunjukan berbeda sangat nyata $(\mathrm{P}<0,01)$.

Superskrip berbeda pada baris yang sama menunjukan berbeda sangat nyata $(\mathrm{P}<0,01)$.

Tabel 5 memperlihatkan interaksi antara penambahan feses ternak dan perekat yang berbeda mempengaruhi kerapatan pemadatan tumpukan pelet unggas dengan nilai berkisar $0,42-0,49 \mathrm{~g} / \mathrm{cm}^{3}$. Hasil penelitian ini lebih rendah dibandingkan yang dilaporkan Handoko (2013) kerapatan pemadatan 
tumpukan pelet yang dipengaruhi lama penyimpanan dan kombinasi Indogofera zollingeriana dan Leucaena leucocephala sebesar $0,63 \mathrm{~g} / \mathrm{cm}^{3}$.

Kerapatan pemadatan tumpukan tertinggi terdapat pada penambahan feses kambing dan tepung sagu yaitu $0,49 \mathrm{~g} / \mathrm{cm}^{3}$ dan terendah terdapat pada penambahan feses kerbau dan putih telur yaitu $0,42 \mathrm{~g} / \mathrm{cm}^{3}$. Hal ini menunjukan semakin tinggi nilai kerapatan pemadatan tumpukan maka nilai kerapatan tumpukan juga akan meningkat. Sesuai pernyataan Luciana (2012) kerapatan pemadatan tumpukan dan kerapatan tumpukan pelet ransum komplit berkorelasi positif, semakin tinggi nilai kerapatan tumpukan maka kerapatan pemadatan tumpukan akan semakin tinggi dan sebaliknya.

\section{Sudut Tumpukan}

Analisis ragam menunjukan
penambahan mempengaruhi $(\mathrm{P}>0,05)$ sudut tumpukan, penambahan feses ternak yang berbeda mempengaruhi $(\mathrm{P}<0,01)$ sudut tumpukan pelet. Interaksi antara penambahan feses ternak dan perekat yang berbeda memberikan pengaruh berbeda sangat nyata $(\mathrm{P}<0,01)$ terhadap sudut tumpukan.
Nilai sudut tumpukan pada penelitian ini berkisar $23,69^{\circ}-29,13^{\circ}$, nilai ini berada pada kisaran pelet dengan kualitas sangat mudah mengalir karena masih berada dikisaran 20-30 ${ }^{\circ}$. Menurut Fasina dan Sokhansanj (1993) pellet dapat dikategorikan sangat mudah mengalir jika nilai sudut tumpukan berada pada kisaran $20-30^{\circ}$.

Syarief dan Halid (1993) dan Khalil (1999) menyatakan selain ukuran partikel (bentuk), kadar air mempengaruhi nilai sudut tumpukan, yaitu semakin tinggi kadar air maka semakin tinggi sudut tumpukan. Nilai sudut tumpukan pellet unggas pada penelitian ini lebih rendah dari yang dilaporkan Syamsu (2007) nilai sudut tumpukan pellet itik dengan bahan perekat dan lama penyimpanan yang berbeda, nilai sudut tumpukan terkecil yaitu $33,31^{\circ}$.

\section{Ketahanan Benturan}

Nilai ketahanan benturan dengan penambahan feses dan bahan perekat yang berbeda dapat dilihat pada Tabel 6 .

Tabel 6. Ketahanan benturan pelet unggas hasil penelitian.

\begin{tabular}{lcccc}
\hline \multirow{2}{*}{ Feses (A) } & \multicolumn{3}{c}{ Perekat (B) } & \multirow{2}{*}{ Rataan } \\
\cline { 2 - 4 } & Tapioka & Putih Telur & Tepung Sagu & \\
\hline Kambing & $90,48 \pm 2,18^{\text {ba }}$ & $93,44 \pm 1,34^{\mathrm{a}}$ & $88,96 \pm 3,72^{\text {ba }}$ & $90,96^{\mathrm{A}}$ \\
Sapi & $92,88 \pm 2,07^{\mathrm{a}}$ & $87,60 \pm 5,54^{\text {ba }}$ & $86,08 \pm 4,51^{\mathrm{b}}$ & $88,85^{\mathrm{A}}$ \\
Kerbau & $76,56 \pm 7,06^{\mathrm{c}}$ & $89,28 \pm 3,17^{\mathrm{ba}}$ & $76,56 \pm 4,98^{\mathrm{c}}$ & $80,80^{\mathrm{B}}$ \\
\hline Rataan & $86,64^{\mathrm{b}}$ & $90,11^{\mathrm{a}}$ & $83,87^{\mathrm{b}}$ & \\
\hline
\end{tabular}

Ket : Superskrip berbeda pada baris dan kolom yang sama menunjukkan berbeda sangat nyata $(\mathrm{P}<0,01)$.

Huruf besar berbeda pada kolom yang sama menunjukan berbeda sangat nyata $(\mathrm{P}<0,01)$

Superskrip berbeda pada baris yang sama menunjukan berbeda sangat nyata $(\mathrm{P}<0,01)$.

Hasil analisis ragam menunjukkan penambahan feses ternak dan bahan perekat yang berbeda mempengaruhi $(\mathrm{P}<0,01)$ ketahanan benturan dan terdapat interaksi antara penambahan feses ternak dan bahan perekat yang berbeda $(\mathrm{P}<0,01)$ terhadap ketahanan benturan pelet, dengan nilai berkisar 76,56\%-93,44\%.
Interaksi antara feses ternak dan perekat yang berbeda mempengaruhi ketahanan benturan diduga dipengaruhi oleh ukuran pelet dan kadar air. McEllhiney (1994) menyatakan faktor yang mempengaruhi ketahanan benturan adalah : 1) karakteristik bahan baku (protein, lemak, serat, pati); 3) density (kepadatan), 4) 
tekstur, 5) air dan 6) kestabilan karakteristik bahan akan menghasilkan kualitas pelet yang baik. Ketahanan benturan pada penelitian ini sama yang yang dilaporkan Pitriani (2016) kerapatan tumpukan pellet silase pelepah kelapa sawit ditambah biomassa indigofera (indigofera zollingeriana) berkisar 99,0499,16\% serta Harmiyanti (2002) ketahanan benturan pellet berperekat lignosulfonat adalah $99,99 \%$ dan pellet berperekat bentonit adalah $99,98 \%$.

\section{KESIMPULAN}

1. Penambahan feses yang berbeda mempengaruhi kadar air, berat jenis, kerapatan tumpukan, kerapatan pemadatan tumpukan, sudut tumpukan dan ketahanan benturan pellet.

2. Penambahan bahan perekat yang berbeda mempengaruhi kerapatan tumpukan, kerapatan pemadatan tumpukan dan ketahanan benturan pellet.

3. Interaksi antara bahan perekat dan feses ternak yang berbeda mempengaruhi kadar air, berat jenis, kerapatan pemadatan tumpukan, sudut tumpukan dan ketahanan benturan pada pelet unggas.

4. Interaksi antara penambahan feses kerbau dan tapioka memberikan hasil terbaik.

\section{SARAN}

Perlu dilakukan penelitian lanjutan untuk mengetahui palatabilitas pellet ayam broiler berbahan feses kerbau dengan bahan perekat tepung tapioka.

\section{DAFTAR PUSTAKA}

Direktorat Bina Produksi. 1997. Kumpulan SNI Ransum. Jakarta : Direktorat Jendral Peternakan. Departemen Pertanian.
Espada, M., Martul, P., Aguayo, A., Grau, G., Vela, A., Aniel-Quiroga, A., 2012. Urinary iodine and thyroid function in a population of healthy pregnant women in the North of Spain. Journal of Trace Elements in Medicine and Biology : Organ of the Society for Minerals and Trace Elements (GMS).27(4):302-6.

Fasina, O. O. \& S. Sokhansanj. 1993. Effect of moisture content on bullhandling properties of alfalfa pellets. Canadian Agric. Engine. 35(4):269-279 (Abstr.).

Handayany, P. 2010. Uji kualitas fisik pellet berbasis jerami jagung sebagai pakan sumber serat untuk ternak ruminansia. Skripsi. Fakultas Peternakan Institut Pertanian Bogor. Bogor.

Handoko, W.A. 2013. Pengaruh lama penyimpanan dan kombinasi Indigofera zollingeriana dan Leucaena leucocephala terhadap kualitas fisik pellet.Skripsi. Fakultas Peternakan. Institut Pertanian Bogor. Bogor.

Harmiyanti, Y. 2002. Uji sifat fisik ransum ayam broiler bentuk pellet dengan penambahan perekat lignosulfonat dan bentonit dengan beberapa proses pengolahan. Skripsi. Fakultas Peternakan. Institut Pertanian Bogor, Bogor.

Hartadi, H., S. Reksohadiprodjo, L. E. Harris, S. Lebdosukoyo dan A. Fillmain. 1990. Tabel Komposisi Pakan untuk Indonesia. UGM Press, Yogyakarta.

Jahan, M. S., Asaduzzaman, M. and Sarkar, A. K., 2006. Performance of broiler fed on mash, pellet and crumble. Int. J. Poultry Sci. $5(3): 265-270$.

Khalil. 1999. Pengaruh kandungan air dan ukuran partikel terhadap perubahan perilaku fisik bahan pakan lokal : Kerapatan Tumpukan, Kerapatan Pemadatan Tumpukan dan Berat Jenis. Media Peternakan. 22(1):1-11. 
Krisnan, R. dan S.P. Ginting. 2009. Penggunaan solid ex-decanter sebagai perekat pembuatan pakan komplit berbentuk pelet: evaluasi fisik pakan komplit berbentuk pelet. Jurnal Teknologi dan Veteriner. 480-486.

Lie, G. H., 1980. The Comparative Nutritional Roles of Sago and Cassava in Indonesia. In: Stanton, W. R. and Flach, M. (eds.), 1980. Sago, theEquatorial Swamp as a Natural Resource. Proceedings of the Second International Sago Symposium, Kuala Lumpur. September 15-17,1979.

Lim, C. 1994. Water Stability of Shrimp Pellet: A Review. Asian Fisheries Sciences, 7:115127.

Luciana, D.Y. 2012. uji kualitas sifat fisik dan daya simpan pellet yang mengandung klobot jagung dan limbah tanaman ubi jalar sebagai substitusi daun rumput gajah. Skripsi. Fakultas Peternakan. Institut Pertanian Bogor. Bogor.

McElhiney, R. R. 1994. Feed Manufacturing Technology IV. American Feed Industry Association, Inc. Arlington, Virginia.

Nugroho, S.J. 2010. Pemakaian Limbah (Sludge) Biogas dari Kotoran Sapi sebagai Sumber Bahan Baku Pakan Nila Oreochromis niloticus. Skripsi. Fakultas Perikanan dan Ilmu Kelautan. Institut Pertanian Bogor. Bogor.

Pitriani, Y. 2016. Kualitas fisik pellet silase pelepah kelapa sawit dengan penambahan biomassa indigofera (indigofera zollingeriana). Skripsi Fakultas Pertanian dan Peternakan. UIN Suska Riau. Pekanbaru.

Rahmayeni. 2002. Uji sifat fisik ransum ayam broiler starter bentuk pellet dengan penambahan perekat onggok. Skripsi. Fakultas Peternakan. Institut Pertanian Bogor. Bogor.
Retnani, Y., N. Hasanah, Rahmayeni dan L. Herawati. 2010. Uji sifat fisik ransum ayam broiler bentuk pellet yang ditambahkan perekat onggok melalui proses penyemprotan air. Agripet.11(1):13-18.

Scott, M. L., Malden C. Nesheim and Robert J. Young. 1982. Nutrition of the Chicken. M. L. Scott \& Associates, Ithaca. New York.

Setyamidjaja, D. 1986. Pupuk dan pemupukan. CV. Simplek., Jakarta. 122 hlm

Sholihah, U. I. 2011. Pengaruh diameter pelet dan lama penyimpanan terhadap kualitas fisik pelet daun legume indigofera sp. Skripsi. Fakultas Peternakan. Institut Pertanian Bogor. Bogor.

Steel R. G. D \& J. H. Torrie. 1995. Prinsip dan Prosedur Statistika, Edisi ke-2, B Sumantri, penerjemah. Jakarta: Gramedia Pustaka Utama. Terjemahan dari: The Principle and Prosedure of Statistics

Suadnyana, I. W. 1998. Pengaruh kandungan air dan ukuran partikel terhadap perubahan sifat fisik pakan lokal sumber protein. Skripsi. Fakultas Peternakan. Institut Pertanian Bogor. Bogor.

Syamsu., 2007. Karakteristik fisik pakan itik bentuk pelet yang diberi bahan perekat berbeda dan lama penyimpanan yang berbeda. Jurnal Ilmu Ternak. 7(2): 128-134.

Syarif, R. dan Halid. 1993. Teknologi Penyimpanan Pangan. Arcan. Jakarta.

Undang., 2002, Pemanfaatan Secara Komprehensif Peternakan Sapi, Jurnal BPTP Jawa Timur. Indonesia.

Vanschoubrock, F., Coucke, L. and van Spaendonck. R., 1971. The Spaendock. R., 1971. The quantitative effect of pelleting feed on the performance of piglets and fattening pigs, Nutr. Abstr. Rev., 41:1-9.

Winarno, F., G. S. Fardiaz dan D. Fardiaz. 1980. Pengantar Teknologi Pakan. PT. Gramedia. Jakarta. 